\title{
The Costs and Benefits of Reducing Complex Disclosures
}

\author{
Sharon Halim*, Yanuar Nanok Soenarno \\ Accounting Department, Atma Jaya Catholic University of Indonesia, South Jakarta, Indonesia \\ *Corresponding author: sharonhalim@yahoo.com
}

\begin{abstract}
Purpose: Reducing annual report disclosure complexity has been a topic of serious debate for standard setters in recent years. In response to that, this study seeks to explore the effect of reducing such complexity on ERC, agency costs, proprietary costs, as well as interest rates on loans given by banks. Methodology: Based on listed companies in Indonesia for the year 2016, required data is collected through the IDX website. All empirical results in this study are obtained through the IBM SPSS Statistics software version 23 using the linear regression function for each hypothesis. Findings: The overall empirical results show that: 1) ERC and proprietary cost is not significantly affected by fog index, suggesting a less effective capital market in Indonesia, where information is not immediately processed in the market; 2) Agency costs are inversely related to disclosure complexity, suggesting that firms producing simpler reports are either mostly involved in tax planning, or larger Indonesian firms with lower fog usually bear higher monitoring costs; and 3) Interest rates on loans given by banks are greatly affected by disclosure complexity. Firms with more complex reports tend to get lower rates on bank loans as compared to those with much more readable reports, suggesting that providing debtholders with more complex information actually reassure them to offer lower rates. Originality: This paper is the first to explore the costs and benefits of reducing disclosure complexity in Indonesia.
\end{abstract}

Keywords: agency cost, annual report readability, complex disclosure, earnings response coefficient, IDX, Indonesia, interest rates, proprietary cost

Cite This Article: Sharon Halim, and Yanuar Nanok Soenarno, "The Costs and Benefits of Reducing Complex Disclosures.” Journal of Finance and Accounting, vol. 6, no. 1 (2018): 9-14. doi: 10.12691/jfa-6-1-2.

\section{Introduction}

With the increasing level of accounting standards complexity and higher demands from financial report users for more information, disclosure readability has been a subject of interest in recent years for regulators, standard setters as well as accounting researchers. Standard setters and regulators such as the Financial Accounting Standards Board (FASB), the International Accounting Standards Board (IASB) and the U.S. Securities and Exchange Commission (SEC) all have ongoing projects related to reducing disclosure complexity. The U.S. SEC Chair, Mary Jo White, in a Leadership Conference [1], claimed that when information conveyed in reports gets too much, it could lead to what is known as 'information overload' - a phenomenon where disclosure becomes ineffective due to too much irrelevant information. This study uses companies' annual reports as the basis of measuring disclosure complexity because it offers the most disclosure on the events that best describe a company's financial and operational conditions. Since these reports are mostly narratives, the clarity of the reports' disclosures is crucial in helping the users understand and interpret the conditions of the company. The main concern today is that users are more likely to jump directly into the figures. Most people find disclosures complex and ambiguous [2], and therefore fail to serve as a useful source of information for decision-making.
Several studies have been trying to analyze the factors affecting complexity, in which most of them relates to earnings quality. Prior researches have shown that companies with complex annual report disclosures purposely use hard-to-understand words in order to obfuscate bad performance [3,4,5,6,7]. For instance, Li [5] examine the implication of disclosure readability and earnings quality measured by earnings persistence and find a significant positive relation between the two. Lo et al. [3] find that firms engaged in earnings management are more likely to disclose complex reports. Based on Bloomfield's [6] discussion of Li [5], there are two most prominent factors affecting the complexity of disclosures. First is obfuscation - which has been mentioned earlier and second is ontology - that is bad news are, by nature, harder to disclose. This in fact contradicts the main purpose of disclosure - that is to provide decision-useful and understandable information for end-users, as well as reducing information asymmetry between ownersmanagers, managers-outsiders, investors-investors as well as government-managers.

Based on companies listed on the Indonesian Stock Exchange (IDX), this study attempts to investigate not the factors affecting complex disclosures, rather the costs and benefits of reducing such complexity. The focus of this study extends to the relation between disclosure complexity and the investors' responsiveness toward earnings as proxied by the earnings response coefficient (ERC). The so-called "bottom line" is commonly believed to be the most useful information available for investors 
$[8,9]$. Ever since the study of Ball and Brown [8], many researchers have tried to explore further the relation between a firm's reported earnings and its returns (i.e. $[10,11,12,13])$. For instance, Beaver [13] show changes in stock returns when annual earnings are disclosed. Ohlson's [12] findings are consistent with that of Beaver's [13]. Another research by Patell and Wolfson [14] find that firms which are expected to disclose some information prior to the option's expiration date have higher option prices. Therefore, in this study, it is expected that with the decreasing level of disclosure complexity, earnings information disclosed will affect investors' responses in a positive manner as shown by the increase in ERC. Furthermore, this study seeks to explore whether a less complex disclosure results in lower agency costs, as reflected by the expense ratio. A higher disclosure readability will more likely result in lower information asymmetry, and therefore agency costs [15].

Despite the benefits, reducing complex disclosures also has its costs. Simplifying disclosures may result in failure of companies to engage in obfuscation and they may unintentionally disclose their disadvantages and that of their owners, thus losing their competitive advantage or ruining the investors' perceptions of the company. These costs are often referred to as proprietary costs $[16,17,18]$. Prior research has shown that in the absence of proprietary costs, manager will follow a full disclosure policy [16], therefore a positive association between readability and proprietary costs is expected.

Aside from proprietary costs, reducing disclosure complexity may also give rise to the increase in interest rates given by loan providers, in this case, banks. A firm's credit opportunities depend on quantity as well as quality of information supplied to potential creditors [12]. In reducing the complexity of annual reports, firms that previously use complex disclosures to obscure bad performance will no longer be able to do so. Creditors may modify loan terms such as decrease the amount of loans, increase the interest rates, and shorten loan maturity in response to poor performance since an increase in corporate risk disclosure may result in higher credit risks [19].

The remaining of the paper proceeds as follows: the next section describes the literature review and hypothesis development. Section 3 discusses the research methodology used, followed by the research findings and analysis in the next section. Last section concludes the paper.

\section{Hypotheses Development}

Fundamental to agency theory is that information asymmetries exist between the preparers and users of financial statements [4,20,21]. Conflict of interests between the different parties give rise to the agency problem, and therefore annual report aims at serving as information intermediary between firm's management and end-users.

The question is whether or not information disclosed in the report is sufficient and effective in helping users make decisions. As information intermediaries, disclosures are expected to provide decision-useful information for users in order to reduce agency problems, hence the agency costs. However, prior researches have shown that many a times firms publish complex disclosures to obfuscate their actual performance [3,4,5,6,7]. For instance, Li [5] finds that firms with poor performance and less-persistent earnings provide disclosures that are more difficult to read. The act of making reports more unreadable or complex is in no way helpful for users such as investors. Of all the information available to investors during the year, net income is believed to capture the most information required for investment decision-making [8]. Kothari [22] claims that when the variability of stock price changes around the earnings announcement date, it can then be concluded that information disclosed in such announcement conveys new information that allows the market to reevaluate its expectations, assuming that there is an efficient capital market for information to be directly processed and reflected in stock prices. Beaver [13] also finds evidence that information outflow increases during earnings announcement period. Based on our outlook of information being useful for investors, we predict that by producing a more readable report, investors will obtain more relevant information that will affect their investment choices, hence increasing the ERC. This brings us to the first hypothesis:

H1. Investors' responsiveness toward earnings is positively related to less complex disclosures.

Firms mainly have incentives to voluntarily disclose relevant information to reduce information asymmetries as well as agency costs [15]. Continuing our initial discussion, many prior researches have shown that firms, however, do not always provide simple disclosure. Bloomfield [6] on his discussion of $\mathrm{Li}$ [5], explains various possible reasons affecting disclosure complexity - obfuscation, ontology, attribution, misdirection, management by exception, conservatism, litigation - in which two most prominent factors according to Lo et al. [3] are obfuscation and ontology, that is they knowingly use hard-to-understand words in order to hide bad performance, or that bad news is by nature harder to disclose, thus more complex. Lo et al. [3] extends $\mathrm{Li}$ 's [5] analysis with increasing specificity related to benchmark beatings and earnings management, and finds that firms that are likely to be involved in earnings management in order to meet or beat prior year's earnings have more complex MD\&A disclosures. Consistent with the previous, Ajina et al. [4] also finds a positive relation between earnings management and disclosure complexity. Assuming an informationally efficient capital market, when companies provide ample, accurate and timely disclosures, agency costs of debt and equity are low [23]. Since complex disclosure contradicts the main purpose of providing understandable and useful information, we can say that the increasing complexity reflects a failure in reducing information asymmetry, and therefore agency costs. Hence the next hypothesis is:

H2. Agency costs are negatively related to less complex disclosures.

Despite the benefits, reducing disclosure complexity also has its costs. Many prior studies [3,4,5,6,7] link firm's performance with disclosure quality. Li's [5] management obfuscation hypothesis argues that managers have incentives to obfuscate information when firm performance is poor because the market may react with a 
delayed incorporation of the information contained in complicated disclosures [6]. Managers may intentionally hide bad performances in order to circumvent negative effects on the firm's stock prices. The main assumption behind it is that higher information processing costs would make it harder for investors to reveal the ugly truth [5]. Reducing complexity of disclosures would reverse the whole point of management's obfuscation hypothesis, and therefore may lead to unintentional disclosing of their disadvantages or that of their owners, diminishing their competitive advantage or ruining the investors' perceptions of the company. Verrecchia [16], Luo et al. [18], and Darrough and Stoughton [17] refers these as proprietary costs. Proprietary costs of disclosing information exist due to the nature of competition - that is the existence of competitors as well as possible market entrants. Proprietary costs can be minimized if information revealed do not result in opponents taking unfavorable actions $[17,18]$. Several other research shows that in the absence of proprietary costs, manager will follow a full disclosure policy $[19,24,25]$. Therefore, we expect that lower disclosure complexity brings rise to proprietary costs.

H3. Proprietary costs are positively related to less complex disclosures.

Besides affecting the competition among firms and decreasing investors' perceptions, reducing disclosure complexity may also affect credits given by financial institutions such as banks. Creditors may modify loan terms such as decrease the amount of loans, increase the interest rates, and shorten loan maturity in response to poor performance [26]. For instance, Tsai et al. [19] find that an increase in corporate risk disclosure results in higher credit risks. If there is a higher level of perceived credit risk, creditors will eventually demand for higher interest rates since they have to bear greater risk that firms may fail to settle loans in the future. Chen et al. [26] finds empirical evidence that relationships between banks and firms previously involved in corporate fraud are negatively affected, which results in lower amount of bank loans and higher interest rates given by the banks. Thus, the forth hypothesis are:

H4. Interest on bank loans is negatively related to less complex disclosures.

\section{Research Methodology}

The sample used in this study is based on companies listed on the Indonesian Stock Exchange (IDX) for the period 2016 (totaling 559 companies) since the annual reports of these companies are easily accessible on the IDX website. Capital market information is obtained from Yahoo Finance. All financial institutions are eliminated in this study as they have different capital structures and mostly do not provide the required data. Other criteria for data exclusion follows Li [5].

\subsection{Disclosure Complexity}

Consistent with previous studies [3,5,27], the annual report readability is measured using the Gunning Fog Index (or simply Fog Index), using the number of words per sentence and the number of syllables per words in determining the complexity of disclosures. Following prior studies, calculation of the index in this study focuses on the Management Analysis and Discussion (MD\&A) section, which contains manager's discussion of past performance and future prospects [5]. The fog index is calculated as follows:

$$
\begin{aligned}
\text { Fog Index } & =0.4 \mathrm{x} \text { (words per sentence } \\
& + \text { percentage of complex words) }
\end{aligned}
$$

The index indicates the number of years of formal education a reader would need to read the text once and understand. Complex words refer to those having three or more syllables per word. Longer sentences and sentences with more complex words will result in the increase of the fog index, hence the disclosure complexity. Consistent with Li [5], Fog 18 means that text is unreadable; 14-18 (difficult); 12-14 (ideal); 10-12 (acceptable); and 8-10 (childish).

\subsection{Earnings Response Coefficient}

Similar to previous study on ERC $[10,28]$, the ERC is calculated by regressing the Cumulative Abnormal Return (CAR), and the unexpected earnings as follows:

$$
\mathrm{AR}_{\mathrm{it}}=\mathrm{R}_{\mathrm{it}}-\mathrm{R}_{\mathrm{i}}
$$

where:

$\mathrm{AR}_{\text {it }}$ Abnormal return of company i's stock in period $t$

$R_{i t} \quad$ Stock return of company $i$ in period $t$

$\mathrm{R}_{\mathrm{i}} \quad$ Expected return of company i's stock in period $\mathrm{t}$

$$
\mathrm{R}_{\mathrm{it}}=\left[\mathrm{P}_{\mathrm{it}}-\mathrm{P}_{\mathrm{i}(\mathrm{t}-1)}\right] / \mathrm{P}_{\mathrm{i}(\mathrm{t}-1)}
$$

where:

$\mathrm{R}_{\mathrm{it}} \quad$ Stock return of company $\mathrm{i}$ in period $\mathrm{t}$

$\mathrm{P}_{\mathrm{it}} \quad$ Company i's stock price in period $\mathrm{t}$

$\mathrm{P}_{\mathrm{i}(\mathrm{t}-1)}$ Company i's stock price in period t-1 (previous period)

$$
R_{i}=\left[I_{t}-I_{(t-1)}\right] / I_{(t-1)}
$$

where:

$\mathrm{R}_{\mathrm{i}} \quad$ Expected return of company i's stock in period $t$

$\mathrm{I}_{\mathrm{t}} \quad$ Market price index value using composite index (in IDX, known as IHSG) in period $t$

$\mathrm{I}_{\mathrm{t}-1} \quad$ Market price index value using composite index (IHSG) in period $\mathrm{t}-1$

Consistent with Ball and Brown's model, the unexpected change in total annual earnings is assumed to be the next period's expectation (Eit) based on current reporting period's earnings (Eit-1). The model is as follows:

$$
\mathrm{UE}_{\mathrm{it}}=\left[\mathrm{E}_{\mathrm{it}}-\mathrm{E}_{\mathrm{it}-1}\right] / \mathrm{E}_{\mathrm{it}-1}
$$

where:

$\mathrm{UE}_{\mathrm{it}}$ Unexpected earnings of company $\mathrm{i}$ in period $\mathrm{t}$

$E_{i t} \quad$ Reported earnings of company $i$ in period $t$

$E_{i t-1}$ Reported earnings of company $i$ in period $t-1$

Therefore, the cumulative abnormal returns is calculated as:

$$
\mathrm{CAR}_{\mathrm{it}}=\alpha_{\mathrm{o}}+\alpha_{1} \mathrm{UE}_{\mathrm{it}}+\alpha_{2} \mathrm{R}_{\mathrm{it}}+\mathrm{e}
$$


where:

$\mathrm{CAR}_{\mathrm{it}}$ Cumulative abnormal return of company $\mathrm{i}$ in period $\mathrm{t}$

$\alpha_{0} \quad$ Constant

$\alpha_{1} \quad$ Slope of regression, the ERC

$\mathrm{UE}_{\mathrm{it}} \quad$ Unexpected earnings of company $\mathrm{i}$ in period $\mathrm{t}$

$\varepsilon \quad$ Sample error

Ball and Brown's [8] theory suggests that the coefficients should be positive and significant if the investors value the changes in the total earnings as price relevant information.

\subsection{Agency Costs}

Previous study (i.e. [29]) related to agency costs use the cost operating ratio and asset utilization ratio as a proxy for agency costs. We use cost operating ratio in this study which is calculated by scaling total operating expenses by total sales for the period. The amount of expense as well as the total sales for the period are obtained directly from the company's annual report available on the company's website and/or on the IDX website.

\subsection{Proprietary Costs}

The proprietary cost referred in this study focuses on the loss of competitive advantage. As discussed earlier, the proprietary cost of providing less complex disclosure is expected to lower as the firm's competitive advantage, in this study, captured by its gross margin.

$$
\text { Gross Margin }(\%)=\frac{(\text { Net Salest }- \text { Cost of Salest })}{\text { Net Salest }}
$$

\subsection{Interest on Bank Loans}

Interest on bank loans may vary from period due to the difference in the amount of loan for the period. Hence, in order to simplify the measurement, interest on bank loans is measured by the weighted average of interest rate given by banks for the period. The information can be easily accessed on the company's notes to financial statements.

\section{Results}

All results in this study is obtained through the IBM SPSS Statistics software version 23 using the linear regression function for each hypothesis.

\subsection{Descriptive statistics}

Table 1. Descriptive statistics for variables used

\begin{tabular}{cccccc}
\hline Variables & Min & Max & Mean & Std. Dev. & $\mathrm{N}^{1}$ \\
\hline Fog Index (full sample) & 11.89 & 21.27 & 17.17 & 1.31 & 338 \\
ERC & 0.67 & 1.28 & 0.97 & 0.15 & 211 \\
- Fog Index & 12.40 & 20.62 & 17.12 & 1.30 & 211 \\
Agency Cost & 0.00 & 0.06 & 0.03 & 0.02 & 95 \\
- Fog Index & 13.77 & 20.30 & 17.17 & 1.28 & 95 \\
Proprietary Cost & -0.03 & 0.49 & 0.22 & 0.13 & 252 \\
- Fog Index & 11.89 & 20.62 & 17.16 & 1.34 & 252 \\
Interest Rate & 0.09 & 0.14 & 0.11 & 0.01 & 196 \\
- Fog Index & 11.89 & 21.27 & 17.11 & 1.38 & 196 \\
\hline
\end{tabular}

${ }^{1}$ The difference between the number of $\mathrm{N}$ in each variable and the full sample is due to data normalization using causewise diagnostics.
Table 1 presents the overall sample statistics. The mean fog index for the whole sample is 17.17, which according to the standard interpretation used by Li [5] is considered “difficult”, and requires at least a high school diploma to understand. This value is similar to those found in $\mathrm{Li}$ [5] and Lo et al. [3], where mean Fog is 18.23 and 18.

\subsection{Earnings response coefficient and disclosure complexity}

Table 2. ERC and disclosure complexity

\begin{tabular}{ccc}
\hline Variables & Beta & t-statistic \\
\hline Constant & 0.946 & 7.181 \\
Fog Index & 0.002 & $0.233(0.816)$ \\
R-square & 0.206 & \\
Adj. R-square & 0.043 & \\
F-statistic & 3.066 & \\
Durbin-Watson & 2.318 & \\
p-value & 0.029 & \\
VIF & 1.005 &
\end{tabular}

Dependent Variable: ERC

$*$, **, *** significant at 0.10, 0.05, 0.01 level.

VIF shows no multicollonearity.

Table 2 shows the results of linear regression for Hypothesis 1. The positive coefficient of 0.002 and a tstatistic of 0.256 is in contrary to our initial hypothesis and is not significant at any level. This finding suggests that the MD\&A section in annual reports may not be the most fundamental piece of information required by Indonesian investors prior to decision making, and therefore complex disclosure in such areas do not affect them significantly. This also suggest that Indonesia is not an efficient capital market, rather a semi-strong form efficient market. In a less efficient market, price changes as a result of earnings surprises is said to be "underreacting" as changes are small and takes time to be recognized in the market $[8,22]$.

\subsection{Agency cost and disclosure complexity}

Table 3. Agency Cost and Disclosure Complexity

\begin{tabular}{ccc}
\hline Variable & Beta & t-statistic \\
\hline Constant & 0.190 & 9.770 \\
Fog Index & -0.009 & $-8.268^{* * *}(0.000)$ \\
R-square & 0.424 & \\
Adj. R-square & 0.417 & \\
F-statistic & 68.360 & \\
Durbin-Watson & 2.152 & \\
p-value & 0.000 & \\
VIF & 1.000 &
\end{tabular}

Dependent Variable: Agency Cost

$*$, **, *** significant at 0.10, 0.05, 0.01 level.

VIF shows no multicollonearity.

The results of Hypothesis 2 are shown in Table 3 . Despite being highly significant at 1 percent and having an adjusted R-square of 41.7percent, the relation between agency cost and disclosure complexity opposes our initial hypothesis. The negative coefficient of -0.009 and t-statistic of -8.268 suggest that with an increase in fog, agency cost decreases. The regression results above 
suggest that in Indonesia, firms with more complex reports tend to have lower agency costs. A reason for this contrary finding may be due to tax planning. Tax planning such as tax avoidance can be done by increasing expenses for the period, and therefore reducing the amount of taxable income for that period. In line with this, Chen et al. [30] find robust evidence that tax planning increases agency costs. Another reason may be because larger firms bears higher information asymmetry between their stakeholders. Li [5] and Lo et al. [3] in their findings prove that firm size is inversely related to the fog index larger firms tend to provide simpler reports since their large-scale investors are mostly aware of the overall conditions of the company. Jensen [31] finds that as firm size increases, more costs are required to monitor and control the firm, hence increasing the agency cost. Larger firms are managed mostly by outsiders - not just owners hence give rise to agency cost $[15,29]$.

\subsection{Proprietary Cost and Disclosure Complexity}

Table 4. Proprietary Cost and Disclosure Complexity

\begin{tabular}{ccc}
\hline Variable & Beta & t-statistic \\
\hline Constant & 0.203 & 1.982 \\
Fog Index & -0.001 & $-0.148(0.883)$ \\
R-square & 0.088 & \\
Adj. R-square & 0.077 & \\
F-statistic & 8.006 & \\
Durbin-Watson & 2.084 & \\
p-value & 0.000 & \\
VIF & 1.029 &
\end{tabular}

Dependent Variable: Proprietary Cost

$*, * *, * * *$ significant at 0.10, 0.05, 0.01 level.

VIF shows no multicollonearity.

The regression result for proprietary cost and disclosure complexity is shown in Table 4. Based on our result, proprietary cost is not significantly related to disclosure complexity at any level, despite having a negative coefficient that is in line with our early hypothesis. This suggests us that information released by Indonesian listed companies through their MD\&A section of the annual reports are not of great attention to their opponents. Proprietary costs are not of huge significance if they do not lead the firms' opponents to take certain unfavorable actions [18]. This further strengthens our conclusion on the first hypothesis - that is Indonesia has a rather semistrong form capital market.

\subsection{Interest rate and disclosure complexity}

Table 5. Interest Rate and Disclosure Complexity

\begin{tabular}{ccc}
\hline Variable & Beta & t-statistic \\
\hline Constant & 0.138 & 14.840 \\
Fog Index & -0.002 & $-2.826^{* * *}(0.005)$ \\
R-square & 0.040 & \\
Adj. R-square & 0.035 & \\
F-statistic & 7.985 & \\
Durbin-Watson & 1.846 & \\
p-value & 0.005 & \\
VIF & 1.000 & \\
\hline
\end{tabular}

Dependent Variable: Interest Rate

$*, * *, * * *$ significant at $0.10,0.05,0.01$ level.

VIF shows no multicollonearity.
Table 5 presents the regression result of our final hypothesis. The negative coefficient of -0.002 and t-statistic of -2.826 is in line with our prediction. Despite the low explanatory levels shown by the adjusted R-square, the relationship between interest rate given by banks and MD\&A disclosure complexity is highly significant at 1 percent. This finding proves that, in Indonesia, companies with less complex disclosures have higher chances of being charged "extra", shown by the higher rates given to them for loans. In line with our underlying theory that simplifying disclosures may expose a firm's poor performance, Chen et al. [26] also find evidence that fraudulent firms will have to bear higher interest rates compared to non-fraudulent ones. This suggest us that, in Indonesia, providing more information by producing more complex reports actually reassure debtholders of their fraudulent-free management with more information on the company, thus lower interest rates.

\section{Conclusion}

This paper is the first to explore the effects of reducing disclosure complexity on several aspects - earlier hypothesized as the costs and benefits - in Indonesia. We initially predicted that with more readable annual reports, ERC will be positively affected, information asymmetry will be reduced - hence lower agency costs, proprietary costs will increase with the increase in proprietary information revealed in a more readable report, and interest rates given by banks as lenders will be higher. Based on our findings, in short, we can say that Indonesia does not have an efficient capital market. Information is not directly processed and reflected in stock prices. However, in line with our initial hypothesis, interest rates given by banks are greatly affected by the fog index. The overall empirical results show that: 1) Investors do not rely on annual reports for their investment-decisionmaking, since fog index do not affect ERC at any significant levels; 2) Agency costs are inversely related to disclosure complexity, suggesting that firms producing simpler reports are either mostly involved in tax planning, or larger Indonesian firms with lower fog usually bear higher monitoring costs; 3) Companies do not gather information on their opponents from their annual reports, since proprietary costs are not significantly affected by disclosure complexity; and 4) Interest rates on loans given by banks are greatly affected by disclosure complexity. We find evidence that firms with more complex reports tend to get lower rates on bank loans as compared to those with much more readable reports, suggesting that providing debtholders with more complex information actually reassure them to modify credit terms and offer lower rates.

This paper is, however, still limited to various constraints. Further research may want to consider using data from the following year after the report is published, and also calculating the fog not only based on MD\&A section, rather the whole report.

\section{Acknowledgements}

The authors would like to thank all parties that have helped in the writing of this paper. To Clarisa, Winia, 
Ivanka, Jacqueline, Irene, Lucy, Kezya, Zefany, Agnes, and Chelsea, for the helpful support and encouragement throughout the process.

This research did not receive any specific grant from funding agencies in the public, commercial or not-forprofit sectors.

\section{References}

[1] White, M. J. (2013). The Path Forward on Disclosure, available at: https://www.sec.gov/news/speech/spch101513mjw (accessed 11 September 2017).

[2] Ben-Shahar, O., Schneider, C. E. More Than You Wanted to Know: The Failure of Mandated Disclosure. Princeton University Press, Princeton, 2014.

[3] Lo, K., Ramos, F., Rogo, R. (2017). Earnings management and annual report readability. Journal of Accounting and Economics, 63, 1-25.

[4] Ajina, A., Laouiti, M., Msolli, B. (2016). Guiding through the fog: Does annual report readability reveal earnings management? Research in International Business and Finance, 38, 509-516.

[5] Li, F. (2008). Annual report readability, current earnings, and persistence. Journal of Accounting and Economics, 45, 221-247.

[6] Bloomfield, R. (2008). Discussion of annual report readability, current earnings, and earnings persistence. Journal of Accounting and Economics, 45, 248-252.

[7] Courtis, J. K. (2004). Corporate report obfuscation: artefact or phenomenon? The British Accounting Review, 36, 291-312.

[8] Ball, R., Brown, P. (1968). An empirical evaluation of accounting income numbers. Journal of Accounting Research, 6, 159-178.

[9] Lev, B. (1989). On the usefulness of earnings and earnings research: Lessons and directions from two decades of empirical research. Journal of Accounting Research, 27, 153-192.

[10] Ariff, M., Fah, C. F. (2011). Accounting earnings response coefficient: An extension to banking shares in Asia Pacific countries. Advances in Accounting, Incorporating Advances in International Accounting, 27, 346-354.

[11] Kormendi, R., Lipe, R. (1987). Earnings innovation, earnings persistence, and stock returns. The Journal of Business, 60, 323-345.

[12] Ohlson, J. A. (1979). On financial disclosure and the behavior of security prices. Journal of Accounting and Economics, 1, 211-232.

[13] Beaver, W. H. (1968). The information content of annual earnings announcements. Journal of Accounting Research, 6, 67-92.

[14] Patell, J. M., Wolfson, M. A. (1979). Anticipated information releases reflected in call option prices. Journal of Accounting and Economics, 1, 117-140.
[15] Jensen, M. C., Meckling, W. H. (1976). Theory of the firm: Managerial behavior, agency costs and ownership structure. Journal of Financial Economics, 3, 305-360.

[16] Verrecchia, R. E. (1983). Discretionary disclosure. Journal of Accounting and Economics, 5, 179-194.

[17] Darrough, M. N., Stoughton, N. M. (1990). Financial disclosure policy in an entry game. Journal of Accounting and Economics, 12 219-243.

[18] Luo, S., Courtenay, S. M., Hossain, M. (2006). The effect of voluntary disclosure, ownership structure and proprietary cost on the return-future earnings relation. Pacific-Basin Finance Journal, $14,501-521$.

[19] Tsai, F-T., Lu, H-M., Hung, M-W. (2016). The impact of news articles and corporate disclosure on credit risk valuation. Journal of Banking \& Finance, 68, 100-116.

[20] Beattie, V. (2014). Accounting narratives and the narrative turn in accounting research: Issues, theory, methodology, methods and a research framework. The British Accounting Review, 46, 111-134.

[21] Beyer, A., Cohen, D. A., Lys, T. Z., Walther, B. R. (2010). The financial reporting environment: Review of the recent literature. Journal of Accounting and Economics, 50, 296-343.

[22] Kothari, S. P. (2001). Capital markets research in accounting. Journal of Accounting and Economics, 31, 105-231.

[23] Botosan, C. A. (1997). Disclosure level and the cost of equity capital. The Accounting Review, 72, 323-349.

[24] Grossman, S. (1981). The informational role of warranties and private disclosure about product quality. Journal of Law and Economics, 24, 461-483.

[25] Milgrom, P. R. (1981). Rational expectations, information acquisition, and competitive bidding. Econometrica, 49, 921-943.

[26] Chen, Y., Zhu, S., Wang, Y. (2011). Corporate fraud and bank loans: Evidence from China. China Journal of Accounting Research, 4, 155-165.

[27] Lawrence, A. (2013). Individual investors and financial disclosure. Journal of Accounting and Economics, 56, 130-147.

[28] Ali, A., Hwang, L-S., Trombley, M. A. (2000). Accruals and future stock returns: Tests of the naive investor hypothesis. Journal of Accounting, Auditing and Finance, 15, 161-181.

[29] Ang, J. S., Cole, R. A., Lin, J. W. (2000). Agency costs and ownership structure. The Journal of Finance, 55, 81-106.

[30] Chen, X., Hu, N., Wang, X., Tang, X. (2014). Tax avoidance and firm value: Evidence from China. Nankai Business Review International, 5, 25-42.

[31] Jensen, M. C. (1986). Agency costs of free cash flow, corporate finance, and takeovers. The American Economic Review, 76, 323-329.

[32] Collins, D. W., Kothari, S. P. (1989). An analysis of intertemporal and cross-sectional determinants of earnings response coefficients. Journal of Accounting and Economics, 11, 143-181. 